\title{
Educate that You May be Free? Religion and Critical Thinking in Post-Boom Ireland
}

\section{Michael Cronin}

\section{Q OpenEdition \\ 12 Journals}

\section{Electronic version}

URL: http://journals.openedition.org/etudesirlandaises/4736

DOI: 10.4000/etudesirlandaises.4736

ISSN: 2259-8863

\section{Publisher}

Presses universitaires de Rennes

\section{Printed version}

Date of publication: 15 December 2015

Number of pages: $75-88$

ISBN: 978-2-7535-4366-9

ISSN: 0183-973X

\section{Electronic reference}

Michael Cronin, «Educate that You May be Free? Religion and Critical Thinking in Post-Boom Ireland », Études irlandaises [Online], 40-2 | 2015, Online since 15 December 2017, connection on 23 April 2019.

URL : http://journals.openedition.org/etudesirlandaises/4736 ; DOI : 10.4000/etudesirlandaises.4736 


\title{
The Vulnerability of the Northern Ireland Settlement: British Irish Relations, Political Crisis and Brexit
}

\author{
Jennifer TodD \\ University College Dublin
}

Abstract

The Good Friday Agreement of 1998 is the cornerstone of stability in Northern Ireland. It is, however, vulnerable to changes in British-Irish relations and priorities. This article argues that this is at the root of recent crises and political stalemate in Northern Ireland. It argues that future shocks - not least the threat of British exit from the EU - are likely to increase instability in Northern Ireland and in North-South relations.

Keywords: Northern Ireland, crisis, Good Friday Agreement, Brexit, North-South relations

Résumé

L'Accord du Vendredi Saint de 1998 est la pierre angulaire de la stabilité en Irlande du Nord. Cependant, il est sensible à l'évolution des relations entre le Royaume-Uni et l'Irlande et des priorités. Cet article démontre que c'est là que se trouve la racine des crises récentes et du climat politique détérioré en Irlande du Nord. Par conséquent, les chocs à venir - dont la menace de la sortie du Royaume-Uni de l'Union européenne n'est pas le moindre - sont susceptibles d'accentuer l'instabilité en Irlande du Nord et dans les relations nord-sud.

Mots clés : Irlande du Nord, crise, Accord du Vendredi Saint, Brexit, Relations nord-sud

\section{Introduction}

It was not unrealistic in May 1998 to see the Good Friday Agreement (GFA) - in the words of its Preface - as a "new beginning" in Northern Ireland, opening up to an agreed politics no longer reducible to ethnic power ${ }^{1}$. This beginning was, however, difficult to sustain. The institutions of Agreement, and in particular the consociational Assembly, became operational only in late 1999 and after a series of crises the Assembly was suspended in 2002 and dissolved in 2003. It was only

1. British and Irish Governments 1998. Agreement Reached in the Multi-Party Negotiations [https://www.dfa.ie/medialdfalalldfawebsitemedialourrolesandpolicies/northernireland/good-friday-agreement.pdf], accessed 22 September 2014. 
under strong British and Irish government pressure that the Northern Irish parties accepted a slightly revised St Andrews Agreement in 2006 and began a new phase of devolved government in 2007. With the devolution of now radically reformed policing and justice to the Assembly in 2010, the implementation of the Good Friday/St Andrews Agreements was declared complete.

The declaration was premature. There was a re-birth of loyalist street protests in winter 2012, increased contention over Orange marches and near political breakdown in winter 2014. Once the British and Irish governments, for different reasons and in different ways, turned their attention away from Northern Ireland, a new phase of political struggle began. As future domestic, European and global problems take precedence over Northern Ireland in British and Irish concerns, crises are likely to recur. Possible British exit from the EU, to be put to referendum in 2017 , is likely to have such impact. Its implications for North-South relations and for settlement in Northern Ireland are the topic of this article.

\section{The vulnerability of the Good Friday Agreement}

The Good Friday Agreement of 1998, with later amendments at St Andrews, is the focal point of agreement between the parties in Northern Ireland. Despite its length and detail, it was always a thin agreement, underspecified in important respects. In those areas where the parties could not reach agreement - in particular the reform of policing and justice - the issues were referred to independent commissions. The formulation of a Bill of Rights for Northern Ireland and the articulation of the principle of "parity of esteem" were referred to the new Northern Ireland Human Rights Commission. Disagreement and conflict on these matters were thus pushed into the future. Other provisions of the 1998 Agreement were conditional. Decommissioning was, notoriously, conditional on the full implementation of the Agreement. Still other provisions remained open to radically conflicting interpretation: while constitutional theorists read the Good Friday Agreement as marking a new concept of sovereignty, based on the will of the people and concerned with principles of governance rather than which state had control, unionists pointed to the paragraphs of the Agreement which insisted that British sovereignty remained unchanged ${ }^{2}$. Thus the years immediately after 1998 were characterized by recurrent crises over decommissioning, demilitarization, executive formation, policing, public symbolism, and the rights

2. E. Meehan, “The Changing British-Irish Relationship: The Sovereignty Dimension”, Irish Political Studies 29.1, 2014, p. 58-75; J. Morison, "Democracy, governance and governability: Civic public space and constitutional renewal in Northern Ireland”, Oxford Journal of Legal Studies 21.2, 2001, p. 287-310; D. Godson, Himself Alone: David Trimble and the Ordeal of Unionism, London, Harper Collins, 2004. 
of the British government to suspend the Assembly ${ }^{3}$. These crises brought down the power-sharing executive and led to the electoral defeat of the more moderate parties (the Ulster Unionist Party and the Social Democratic and Labour Party) by the more extreme parties in their blocs, the Democratic Unionist Party (DUP) and Sinn Féin.

Far-reaching reforms of policing and justice were gradually implemented by the British government, in consultation with the Irish. In the new post 9/11 climate, IRA decommissioning eventually was completed by 2005, and British demilitarization by 2006. With these issues resolved, the two governments were able to bring the parties back to agreement. At St Andrews in 2006, both governments made it clear to the dominant parties, the DUP and Sinn Féin, that if one of them turned away from agreement, the alternative would be worse for it. With the formation of a new devolved administration in 2007, and by 2010 with the devolution of policing and justice to Northern Ireland, implementation was declared complete.

It was not complete. There was no Bill of Rights for Northern Ireland and cultural and community relations issues had only partially been addressed. Most important of all, there remained radical disagreement between the Northern Irish parties on the way that key terms and principles of agreement would be interpreted. The parties disagreed profoundly about its overall geopolitical significance and as to what followed constitutionally, institutionally and culturally ${ }^{4}$. Did the GFA and St Andrews, as unionists asserted, strengthen the Union, or did they, as republicans believed, hollow it out? Did British sovereignty in Northern Ireland now have any cultural implications? Was the central feature of sovereignty now the principle of multi-levelled governance rather than the fact of state power? Was the basis of British sovereignty now the will of the people of Ireland, expressed in referenda? On these questions rested others: the meaning of "parity of esteem"; the appropriate forms of public symbolism.

The conflicting perspectives of unionists and nationalists on the principles of agreement meant that crises remained endemic. Crises occurred as each new issue arose, and as new circumstances gave rise to new questions of implementation, and without common principles the Northern Ireland parties were unable to resolve them. After 1998 adjudication on the meaning and principles of the Agreement had taken place informally, by British-Irish negotiation, in precisely

3. J. Ruane and J. Todd, "The Politics of Transition? Explaining Political Crises in the Implementation of the Belfast (Good Friday) Agreement", Political Studies 49 (5), 2001, p. 923-940.

4. J. Ruane and J. Todd, Ibid.; J. Tonge, J. M. Braniff, T. Hennessey, J. W. McAuley and S. A. Whiting, The Democratic Unionist Party: From Protest to Power. Oxford, Oxford University Press, 2014; P. Shirlow, J. Tonge, J. McAuley and C. McGlynn, Abandoning Historical Conflict? Former Paramilitary Prisoners and Political Reconciliation in Northern Ireland, Manchester, Manchester UP, 2011. 
the way that the broad terms of the Agreement had themselves been drafted. In effect, the principles of agreement were safeguarded by British-Irish definition and assertion of them.

This informal mode of safe-guarding the principles of the Agreement was initially functional, at least for the two states involved. It suited the modus operandi of the United Kingdom which functions without a written constitution, and where the habits of territorial governance have traditionally and to the present involved informal agreements, flexibility, consensus, rather than appeal to law ${ }^{5}$. It also suited the Irish state which had gained a degree of autonomy by skilful political balancing of its three large, powerful and significant partners - the UK, the US and the EU. The overwhelming political presence of the UK was balanced by a strong diplomatic initiative in the USA which at once reduced US support for violent republicanism and brought in the US on the side of constitutional nationalism, with the EU brought into play as a model of shared sovereignty and a legitimator of Irish aims $s^{6}$. The resulting settlement was seen as a diplomatic triumph for a small state which gradually and through dialogue and persuasion shifted the direction of British state policy in Northern Ireland ${ }^{7}$. Irish elites saw no reason to change a diplomatic style which had worked so well.

This informal British-Irish mode of implementing the Agreement and of adjudicating on its principles was, however, dependent on the states' prioritization of Northern Ireland. After 2010, this weakened. Economic collapse in the South removed Northern Ireland from the forefront of Irish government attention. The British government's attention was increasingly focused on the dangers of Scottish independence, and on increasing public dissatisfaction with the EU expressed in popular support for the United Kingdom Independence Party (UKIP). With new administrations in each jurisdiction by 2011, a new strand of British-Irish policy was launched, focused this time on mutual British-Irish relations, rather than on Northern Ireland ${ }^{8}$.

5. R. Rose, Understanding the United Kingdom: The Territorial Dimension, London, Longman, 1982; J. Bulpitt, Territory and Power in the United Kingdom: An Interpretation. Manchester, Manchester University Press, 1983; Robert Hazell (ed.), The state and the nations: the first year of devolution in the United Kingdom, London, The Constitution Unit/Imprint Academic, 2000.

6. E. Meehan, "The European context: changing forms of territorial politics in the United Kingdom”, in J. Coakley, B. Laffan and J. Todd (eds.), Renovation or Revolution? New Territorial Politics in Ireland and the United Kingdom, Dublin, UCD Press, 2005, p. 147-165.

7. J. Ruane and J. Todd, "History, structure and action in the settlement of complex conflicts: the Northern Ireland case", Irish Political Studies, 29-1, 2014, p. 15-36; J. Todd, "Thresholds of State Change: Changing British State Institutions and Practices in Northern Ireland after Direct Rule", Political Studies 62 (3), 2013, p. 522-538.

8. P. Gillespie, "The Complexity of British-Irish Interdependence", Irish Political Studies, 29.1, 2014, p.37-57; J. Coakley and J. Todd (eds.), Breaking Patterns of Conflict in Northern Ireland: The British and Irish States, London, Routledge, 2014. 
The process brought a new British-Irish rhetoric of "best friends" which portrayed British-Irish relations as unconditionally positive. Senior Irish and British officials and politicians emphasized the wonderfully improved relationship between Britain and Ireland, the important trading relations, the intermingling and interconnections of peoples, the family ties? ${ }^{9}$. Paul Gillespie takes this as indicative of a "normalisation" of British-Irish relations and a recognition by the Irish of the fact of "interdependence" rather than either dependence or independence. The removal of the territorial claim to Northern Ireland from the Irish Constitution is typically seen to have helped this normalisation ${ }^{10}$.

Relations in Northern Ireland, however, deteriorated as British-Irish oversight slackened. Northern Ireland was left to agree on remaining issues of implementation (rights, cultural policy, community relations policy) and new economic and heritage projects. Implementation was very slow. No Bill of Rights for Northern Ireland was agreed. The promise of a successor to the 2005 "Shared Future" strategic framework on community relations remained unfulfilled until 2010 when the executive produced a new consultation document on the topic ("Integration, Sharing and Cohesion"), quickly withdrawn in the face of criticism by the entire range of rights and community relations activists ${ }^{11}$. A new set of proposals was put forward in 2013 but it was overshadowed by increasing political conflict ${ }^{12}$. New EU funded projects were agreed after much discussion - a Maze Heritage Centre, on the site of the old Long Kesh/Maze prison where the republican hunger strikes had occurred and where loyalists had also been incarcerated, and the construction of a bridge (Narrow Water Bridge) to link South Down in Northern Ireland directly with North County Louth in the Irish state ${ }^{13}$. Unionists were uneasy with each project, and later withdrew their support from each, in the process losing EU funding. Meanwhile very substantive disagreement over the nature of the St Andrews Agreement of 2006 continued (see Tonge on DUP views ${ }^{14}$ ).

Conflict was initially over those aspects of the GFA and St Andrews that had still not been implemented - cultural equality (flags on council buildings), the

9. B. McDonagh, "Irish Friends and Friends of Ireland...”, London Speeches 2009-2013, Dublin, Institute of Irish and European Affairs, 2014.

10. J. Coakley, "The Belfast Agreement and the Republic of Ireland", in R. Wilford, (ed.), Aspects of the Belfast Agreement, Oxford, Oxford University Press, 2001, p. 223- 244.

11. J. Ruane and J. Todd, “From 'A Shared Future' to 'Cohesion, Sharing and Integration': An Analysis of Northern Ireland's Policy Framework Documents”, Prepared for Joseph Rowntree Charitable Trust, 2011, [www.jrct. org.uk/core/documents/download.asp?id=429].

12. K. Hayward, "Deliberative Democracy in Northern Ireland: Opportunities and challenges for consensus in a consociational system" in J. Ugarizza and D. Caluwaerts (eds.), Democratic Deliberation in Deeply Divided Societies: From Conflict to Common Ground, Palgrave Macmillan, 2014, p. 11-34.

13. The former was awarded 18 million euros under EU PEACE III funding, the latter 17 million euros under EU INTERREG funding.

14. J. Tonge, J. M. Braniff, T. Hennessey, J. W. McAuley and S. A. Whiting, The Democratic Unionist Party: From Protest to Power, op. cit. 
past (the Maze heritage centre), and parity of esteem (legislation on the Irish language). Sections of the unionist population, sensing a political vacuum and the prospects of pushing back perceived republican gains, mobilized and won increasing unionist sympathy over a whole range of issues to do with "culture" and "the past". Belfast City Council's decision in December 2012 no longer to fly the British flag every day of the year provoked months of loyalist mobilization and rioting and the protest gained wider unionist support ${ }^{15}$. Meanwhile the British and Irish governments stood back, intent to let the Northern Irish parties resolve the conflicts themselves. They failed to agree even after mediation attempts by US figures, Richard Haass and Meghan O'Sullivan ${ }^{16}$. By late 2014 there was paralysis of shared government in Northern Ireland. It was resolved, temporarily at least, only when the British and Irish governments reengaged in negotiations with the Northern Ireland parties and convened the Stormont House talks. A new "Stormont House" Agreement was reached in December 2014.

The sequence of events shows the vulnerability of settlement in Northern Ireland to external events and shocks, in particular to those that weaken British and Irish commitment to hands-on oversight of Northern Ireland affairs. Possible British exit from the European Union (Brexit) will only increase this vulnerability. Gillespie is correct that it could change the game for unionists in Northern Ireland, and if it led to renewed mobilization for Scottish independence it could make a united Ireland preferable to marginalization in an English-dominated rest of the $\mathrm{UK}^{17}$. But that would require enough social stability to allow rational public assessment of the options. If instead Brexit rolled back the achievements of the Good Friday Agreement and weakened still farther British-Irish oversight of Northern Ireland, it is more likely to encourage unionist activists to mobilise against other aspects of the Agreement(s) with dangers of a return to conflict.

I argue below that in the short term Brexit is indeed likely to roll back the GFA. It is likely to impact on peace and stability in Northern Ireland by affecting North-South relations, in particular the role of the Irish border, the North-South institutions set up with the Good Friday Agreement (GFA) of 1998, in particular the Special EU Programmes Body set up to administer INTERREG and PEACE funding, and EU funding itself. In the remainder of the article I show why, and

15. P. Nolan, D. Bryan, C. Dwyer, K. Hayward, K. Radford, and P. Shirlow, The Flag Dispute: Anatomy of a Protest, Belfast, Queen's University Belfast, December 2014, [http://pure.qub.ac.uk/portal/files/13748797/ The_Flag_Dispute_report_PRINTED.pdf, accessed 15 March 2015.

16. P. Nolan, Northern Ireland Peace Monitoring Report. Number Two, Belfast, Community Relations Council, 2013; P. Nolan, Northern Ireland Peace Monitoring Report. Number Three, Belfast, Community Relations Council, 2014.

17. D. O Ceailleagh, and P. Gillespie (eds.), Britain and Europe: the Endgame. An Irish Perspective, Dublin, Institute of International and European Affairs, 2015. 
I argue that imaginative cross-border responses are necessary and will be of value even if Brexit is avoided.

\section{图 North-South Relations}

North-South relations are one pillar of peace and settlement in Northern Ireland. The need to open up these relations was a continuous strand of Irish government thinking at least from the time of Taoiseach Jack Lynch's Foreign Affairs article ${ }^{18}$. A North-South momentum was central to the GFA; it is key to economic development on the island; and it is important for the easing of relations and the relaxation of attitudes on both sides of the border.

Mutual British and Irish EU membership helped North-South relations in a number of ways:

- Funding for peace and cross-border projects

- The form of North South implementation bodies

- Softer concepts of sovereignty and models of multi-levelled governance

- Openness of cross-border crossing, employment, and trade

- Legitimation internationally of the GFA.

Brexit threatens this. It removes one North South implementation body set up with the GFA - the Special EU Programmes Body (SEUPB) - and potentially undermines the others. It removes an important source of economic funding and cooperation. It threatens the openness of the border, and thus stands to increase political polarization. It may encourage a move back to more exclusivist concepts of sovereignty in Britain and among sections of unionists in Northern Ireland. And it threatens the institutions set up under the GFA, in particular the form and functions of the North-South implementation bodies, and the promise of equivalent rights and equality provisions in the two jurisdictions.

A parallel threat to Nordic cooperation, institutionalized in the Nordic Council, occurred when Finland and Sweden joined the EU in 1995. McQuaid ${ }^{19}$ shows how the Nordic Council struggled to identify areas where it still made sense to cooperate. The consequences for North-South relations are likely to be even more serious, since on them depends not just cooperation but also internal stability in the North.

18. J. M. Lynch, "The Anglo-Irish Problem”, Foreign Affairs, 50: 4, 1972, p. 601-617.

19. S.D. McQuaid, "Nordic Horizons for a 'Council of the Isles'? Instituting Regional Cooperation”, in Gerry Hassan and James Mitchell, (eds.), After Independence: The State of the Scottish Nation Debate, Edinburgh, Luath Press Limited, 2013. 


\section{Open borders, North-South trade and linkages}

The openness of the North-South border is one of the great achievements of the last two decades. Together with the equalization process in Northern Ireland, this has removed the urgency of the Northern nationalist demand for a united Ireland. British sovereignty in Northern Ireland no longer impacts on the cultural identity or legitimacy of constitutional views of nationalists. Nor are they cut off from the rest of the island, and a path to greater institutional integration is in principle open, short of constitutional change. Recent surveys show that more nationalist voters now prefer to stay in the new Northern Ireland than move to a united Ireland ${ }^{20}$. This, however, is because British sovereignty no longer carries with it implications for internal power, cultural status or freedom of movement.

The opening of the Irish border depends on two pillars - peace and the EU framework. Without peace there would be constant security checks; without the EU there could be constant customs and immigration checks.

In the recent past - up until the 1990s - cross-border trade was badly affected by the border. At recent seminars in University College Dublin (10 December 2009; 18 November 2009; 10 February 2010) business leaders remembered the difficulty of any cross-border trade in the 1970s and 1980s, the constant delays at the border, the danger, the intimidation. And it was business that played a major role in pushing for an opening of the border and the development of an islandwide economy ${ }^{21}$.

Even more important, the openness of the border changes the quality of life on each side of it. The effect of violence was to cut the North off from the rest of the island: roads barred; farms cut in half; security checks; Northerners stigmatized in the South; people in the border areas - North and South - constantly worried about security, constantly suspicious. It takes time to overcome this. Even in the early 2000s, distrust, silence and avoidance of discussion of North-South issues were evident in the border area ${ }^{22}$. Recent research in 2014 shows that this has at last changed: in the Louth-Dundalk area, for example, respondents say that political differences and the border itself are less important to them than before $e^{23}$.

20. D. Morrow, G. Robinson and L. Dowds, "The long view of community relations in Northern Ireland 1989-2012”, ARK Research Report, 2013, [http://www.ofmdfmni.gov.uk/the-long-view-of-community-relations1989-2012-dec-2013.pdf, accessed 19 January 2014.

21. Sir G. Quigley, "North-South cooperation in 2013: towards an ever closer working relationship. Interview with Sir George Quigley", Journal of Cross-Border Studies in Ireland, No 8, 2013, p 15-29; K. Hayward, and E. Maginnis, "The business of building peace: Private Sector Cooperation across the Irish Border", Irish Political Studies, 22.1., 2014, p. 154-175.

22. J. Todd et al., "The moral boundaries of the nation: nation, state and boundaries in the Southern Irish border counties", Ethnopolitics 5 (4), 2006, p. 365-382.

23. Ongoing research by the author. 
It is possible to be relaxed about the border from each side, and thus again for British sovereignty to be less restrictive for Northern nationalists.

If there is Brexit then the border will again become important and perhaps more so since it will be a border of the EU. Unless the Irish state forgoes freedom of movement (of goods and peoples) within the EU, or the UK forgoes freedom of movement between Northern Ireland and the rest of the UK, they logically have to lessen freedom of movement across the Irish border. This impacts trade. It encourages a border-mentality of suspicion and surveillance. It will undoubtedly impact on the quality of life of border-dwellers and on the satisfaction of Northern nationalists.

\section{Institutions: the SEUPB and the North-South bodies}

The North-South Council and the related implementation bodies are central parts of the architecture of the GFA, co-dependent with the Assembly.

The Special EU Programmes Body (SEUPB) is one of the six original North South implementation bodies. Other North South bodies set up as part of the North-South Council include Intertrade Ireland; Waterways Ireland; Irish Lights; Language Body; Food Safety (for discussion of their tasks and performance in the first five years, see Coakley, "The North-South relationship: Implementing the Agreement", published in 200524). There is also significant institutional harmonization on tourism, and small but increasing cooperation in health (opening Crumlin Children's Hospital in Dublin for heart surgery for children from the North) and education.

The main function of the SEUPB is to "manage cross-border European Union Structural Funds programmes in Northern Ireland, the Border Region of Ireland and parts of Western Scotland". It has managed the INTERREG and the PEACE (most recently PEACE III) programmes. Its present work involves implementing a new 240 million euro INTERREG cross-border co-operation programme for the Border Region of Ireland, Northern Ireland and Western Scotland for 2014-2020.

Setting up the North South Council and implementation bodies involved path-breaking work in harmonizing working conditions for Northerners and Southerners within these institutions: this included complex details like equivalent pension entitlements for all employees. The bodies provide an original model of trans-state institution-building within the EU.

In the event of Brexit, the SEUPB will become redundant in its present form. Indeed it is likely that the wider institutional architecture of the North-South bodies

24. J. Coakley, "The North-South relationship: Implementing the Agreement", in J. Coakley, B. Laffan and J. Todd (eds.), Renovation or Revolution? New Territorial Politics in Ireland and the United Kingdom, Dublin, UCD Press, 2005, p. 110-131. 
will be challenged as greater divergence in laws and policy requirements follow a British exit from the EU. If freedom of trade is restricted, InterTrade Ireland may be unable to fulfill its remit to foster cross border trade. If the UK moves away from EU regulations on employment, so the internal structure of the North South bodies will need to be reconfigured. All of this reacts back on the GFA itself, challenging the structure of the Agreement. It is therefore politically destabilizing.

The initial question concerns the role of the SEUPB if the UK leaves the EU. In the most benign scenario, the two governments might negotiate with the EU a special position for Northern Ireland to enable a continued drawdown of funding. To negotiate this will require an urgency of focus and a convergence of aims between the governments, the more difficult because such a special position for Northern Ireland is likely to require some matching British financial contribution. Even if existing EU funding continues, the drawdown of new funding - and thus the continued role of the SEUPB into the future - is far from guaranteed. And even in the most benign of circumstances, the new challenges will require significant amendments within the North South institutions and in their remit (depending on UK changes in policy). Short of the most benign of circumstances, it will be politically imperative to reconfigure the form, nature and remit of the North-South implementation bodies and the role of the North-South Council: in effect it will be necessary to revise the North-South institutions set up under the GFA in order to keep to the principles of the Agreement.

\section{Funding - INTERREG and PEACE funding}

If the UK leaves the EU, then EU funding for cross border projects will be threatened. SEUPB is responsible for EU funding of up to one million Euro, although with the decline of the peace programmes the actual funding has itself declined: as noted above, recent investment includes an INTERREG grant of a quarter of a million euros over 6 years.

Important as these contributions are, they pale beside the British subvention to Northern Ireland. Calculating the "subvention" is controversial depending on whether or not we include universal benefits across the United Kingdom (eg unemployment, health) ${ }^{25}$. But public expenditure in Northern Ireland far outruns revenue generated from Northern Ireland, in $2010-11$ by $£ 9.6$ billion. However we calculate the "subvention" within this, it dwarfs EU and North-South funding.

It is sometimes argued that EU funding is thus insignificant to Northern Ireland. But this neglects its social and political as well as economic importance.

25. See [http://www.nicva.org/sites/default/files/d7content/attachments-articles/calculating_public_spending_and_revenue_in_northern_ireland_0.pdf, accessed 11 April 2015. 
It supports cross-community and North-South endeavors and contact: so, for example, numerous small bodies have benefitted from PEACE funding, from community groups in the border area to local museums with cross-border educational projects. These small local projects have a cumulative effect in improving cross community and cross border relations. There are also larger projects of potential economic as well as social importance. If the UK votes itself out of the EU a Conservative government committed to financial rectitude is unlikely to spend on such projects even if they are only a small proportion of current expenditure on Northern Ireland.

Moreover even were funding available - as it was for Narrow Water Bridge and the Maze Heritage Centre - drawing it down depends on political agreement. As political agreement declines - and I have argued that this is highly likely with Brexit $-\mathrm{a}$ vicious circle develops with less funding available and less funding demanded for initiatives which create more open relations and more satisfied citizens.

\section{圈 New North-South linkages}

In the event of Brexit, there will be a major impact on North-South relations. The border will become more important in trade, in interaction, and probably in perception and ideology. The North-South implementation bodies are likely to be weakened and perhaps rendered redundant. EU funding stands to be lost. These losses will be significant economically and socially, and even more so politically since the GFA - and stability in the North - rests on a North-South dimension.

It will be urgent to compensate for these losses: by opening new cross-border linkages and institutions; by negotiating new areas of funding; and by using the special position of Northern Ireland within the UK to maintain EU support for North-South projects and relations. Even if Brexit does not happen, it is for everyone's benefit to reinvigorate North-South interrelations within the agreed constitutional parameters of the GFA. In the 1990s it was common to say that the momentum of the peace process had to be sustained: like riding a bicycle, if the momentum stopped one fell off. That momentum was (nearly) stopped from 2012-4. Strengthening North South relations in new circumstances can renew the momentum, and provide greater stability in both parts of the island in the event of future exogenous shocks. The following areas are important

\section{Special EU funding for North-South projects}

Could a British government after Brexit accept that Northern Ireland (in its North-South relations) have a different relation with the EU than the rest of the 
UK? This would be constitutionally anomalous, but not insurmountably so. The past thirty years have seen growing flexibility in concepts of sovereignty within the UK, and most particularly in respect to Northern Ireland ${ }^{26}$. Northern Ireland, while remaining under British sovereignty, is already constitutionally anomalous within the UK because of (i) the guarantee in the GFA that British sovereignty rests on the consent of a majority (ii) the North-South strand of the GFA which provides for small but exemplary forms of institutional integration (iii) the role of the Irish state in conflict management in Northern Ireland, agreed in the Anglo Irish Agreement of 1985 and since further developed.

Could the EU give special treatment to North-South relations even after Brexit? The EU has consistently proven itself sympathetic to peace-building in Northern Ireland, conditional on this being within a framework agreed by the two governments. And while special EU treatment for Northern Ireland would undoubtedly involve some British financial input, the alternative - if it led to political breakdown - would be more costly for the British government.

In recognition of these considerations, the Irish parliamentary Committee on European Affairs ${ }^{27}$ has called for bilateral British and Irish negotiation to have the special position of Northern Ireland in the UK recognised in an EU context.

\section{New political linkages and modes of representation}

New political linkages and modes of representation could counterbalance the effects of Brexit. Garret FitzGerald once suggested that the Republic represent Northern farmers in the EU. Northern farmers might well welcome some special sectoral linkages with the South. Indeed one might envisage complex linkages for different sectors, some between North and South, some between Northern Ireland and Scotland if as is probable the Scots move towards independence after Brexit ${ }^{28}$.

Other linkages might also be imagined - for example between Northern border constituencies and MEPs in Southern border areas.

Of course here we come into complex legal territory in each jurisdiction and in the EU. But the lessons of the last thirty years of British-Irish negotiations are that innovative and mutually beneficial agreements can be developed by working within this complex and sensitive territory ${ }^{29}$.

26. E. Meehan, “The European context: changing forms of territorial politics in the United Kingdom”, 2005, op. cit.; E. Meehan, "The Changing British-Irish Relationship: The Sovereignty Dimension”, 2014, op. cit.

27. Houses of the Oireachtas, Joint Committee on European Affairs Report: UK/EU Future Relationship: Implications for Ireland, June 2015, [http://www.oireachtas.ie/parliament/medialcommittees/euaffairs/23-6-15-Report-UK-EUFuture-Relations.pdf], accessed July 202015.

28. P. Gillespie, "The Complexity of British-Irish Interdependence”, 2014, op. cit.

29. J. Ruane and J. Todd, "History, structure and action in the settlement of complex conflicts: the Northern Ireland case", 2014, op. cit.; J. Ruane and J. Todd, "History, structure and action in the settlement of complex 


\section{multi-levelled action}

It is clearly necessary to have action at many levels:

- Top-level British-Irish planning for different eventualities.

- North-South discussions on how the potential losses of Brexit can be counter-balanced. Here the new North-South parliamentary body set up in 2012, together with the North-South Council, provide forums for discussion.

- Strong involvement of interest groups with common cross-border interests, for example business, farmers, health sector.

- Strong public involvement. The recent Constitutional Convention and Irish Citizens' Assembly suggests that carefully constructed North-South citizens' discussion might show ways of opening new linkages to mutual benefit ${ }^{30}$.

- Comparative learning: The Nordic Council, and in particular the Freedom of Movement Council that it set up in 2014 to remove obstacles to freedom of movement across the Nordic states, including between EU and non-EU member states, gives a model of how some of the effects of EU borders can be compensated by an additional layer of regional integration ${ }^{31}$.

\section{圈 Conclusion}

There is little internal momentum within the Northern Ireland settlement. It is prone to crisis when not watched over by the British and Irish states. In this respect, preparing for Brexit can strengthen the settlement by increasing the strength of North-South linkages, within the constitutional constraints of the GFA.

It has been tempting to put the problem aside until after the British general election, or after British negotiations begin within the EU, or after a referendum. However a reworking of the North-South dimension can be of mutual benefit even if Brexit does not happen. Re-starting a momentum of mutual dialogue and mutual benefit can strengthen settlement in Northern Ireland, and allow it to survive the inevitable sequence of future shocks, of which Brexit may only be one.

conflicts: the Northern Ireland case", 2014, op. cit.

30. J. Suiter, D. Farrell and E. O'Malley, "When do deliberative citizens change their opinions? Evidence from the Irish citizens' Assembly”, International Political Science Review, 2014. DOI: 10.1177/0192512114544068.

31. [http://www.norden.org/en/nordic-council-of-ministers/ministers-for-co-operation-mr-sam/freedom-of-movement/ freedom-of-movement-council], accessed 11 April, 2015. 